\title{
Fluoride Concentration of Some Brands of Fermented Milks Available in the Market
}

Carolina Simonetti Lodia

Michele Maurício Manarelia

Kikue Takebayashi Sassaki ${ }^{b}$

Alberto Carlos Botazzo Delbem ${ }^{a}$

Cleide Cristina Rodrigues Martinhon ${ }^{a}$

\section{ABSTRACT}

Objectives: To evaluate the fluoride ion concentration in some fermented milks present in the market.

Methods: Three brands of 6 fermented milks (Parmalat ${ }^{\circledR}$-uva, Chamyto $®$, Paulista $®$, Batavito $®$, Yakult $\circledast$, Vigor Club $®$ ) were analyzed. Fluoride concentration was evaluated after facilitated microdiffusion by HDMS.

Results: Parmalat ${ }^{\circ}$ products ranged from $0.022 \mu \mathrm{gF} / \mathrm{g}$ to $0.031 \mu \mathrm{gF} / \mathrm{g}$, Chamyto ${ }^{\circledR}$ from 0.228 $\mu \mathrm{gF} / \mathrm{g}$ to $0.272 \mu \mathrm{gF} / \mathrm{g}$, Paulista ${ }^{\circledR}$ from $0.182 \mu \mathrm{gF} / \mathrm{g}$ to $0.220 \mu \mathrm{gF} / \mathrm{g}$, Batavito ${ }^{\circledR}$ from $0.028 \mu \mathrm{gF} / \mathrm{g}$ to $0.030 \mu \mathrm{gF} / \mathrm{g}$, Yakult $\AA$ from $0.115 \mu \mathrm{gF} / \mathrm{g}$ to $0.206 \mu \mathrm{gF} / \mathrm{g}$ and Vigor Club $®$ from $0.808 \mu \mathrm{gF} / \mathrm{g}$ to 1.171 $\mu \mathrm{gF} / \mathrm{g}$.

Conclusions: The presence of fluoride could be observed in all of the fermented milks analyzed which can contribute with the total fluoride daily intake. (Eur J Dent 2011;5:139-142)

Key words: Fluoride; Dental fluorosis; Milk-fermentation; Children.

a Department of Pediatric Dentistry, Araçatuba School of Dentistry, Paulista State University (UNESP),

São Paulo, Brazil.

b Department of Basic Sciences, Araçatuba School of Dentistry, Paulista State University (UNESP), São Paulo, Brazil.

- Corresponding author: Carolina Simonetti Lodi Department of Pediatric Dentistry, Araçatuba School of Dentistry, Paulista State University (UNESP)

Rua José Bonifácio, 1193

16015-050-Araçatuba, São Paulo, Brazil.

Phone: +551836363235

E-mail: carol_lodidyahoo.com.br

\section{INTRODUCTION}

The role of fluoride in dental caries prevention is well established. However, ingestion of excessive fluoride during tooth development can cause dental fluorosis. ${ }^{1}$

Dental fluorosis is a deficiency in enamel mineralisation due to excessive daily fluoride intake during tooth development and its severity is directly related to the absorbed dose of this ion. Since the dose-effect relationship is not precisely known, the dose of $0.07 \mathrm{mg} F /$ day/kg of body weight 
has been accepted as the upper limit in terms of the clinically acceptable risk of dental fluorosis. ${ }^{2}$

The main sources of fluoride intake are fluoridated water, powdered milk reconstituted with fluoridated water, inadvertent ingestion of fluoridated toothpaste, inappropriate use of dietary supplements, as well as foods and beverages processed with fluoridated water. ${ }^{3-5}$

During infancy and childhood (36-48 months), the fluoride intake in diet deserves special attention. This period coincides with the calcification of different stages of the developing permanent teeth crowns. This is also a critical time for ensuring that the optimal levels of ingested fluoride are not exceeded. ${ }^{3}$

Several previous studies have determined the fluoride content of children's foods, such as milk, $, 0,7$ dinners and desserts ${ }^{8-11}$ and beverages. ${ }^{5,12,13}$ However, the fluoride concentration in many child addressed products remains unknown. Thus, the aim of this study was to evaluate the fluoride ion concentration in some fermented milks present in the market.

\section{MATERIALS AND METHODS}

Three lots of six different brands of fermented milks, with $80 \mathrm{~g}$ each bottle, were analyzed: Parmalat $\AA$-uva, Chamyto $\AA$, Paulista $\AA$, Batavito $®$, Yakult $®$, Vigor Club $₫$.

The products were opened on the day of the analysis and $2 \mathrm{~mL}$ of each fermented milk was used in this experiment. Fluoride concentrations were determined after overnight hexamethyldisiloxane (HMDS)-facilitated diffusion ${ }^{14}$ as modified by Whitford, using a fluoride ion-specific electrode Imodel 9409, Thermo Electron Corporation, Beverly, MA, USA) and a miniature calomel reference electrode (Accumet, \#13-620-79: Fischer Scientific, Pittsburgh, PN, USA), coupled to a potentiometer (290A, Orion Research Inc., Boston, MA, EUA). During the diffusion process, which was conducted at room temperature, the solutions in the nonwetable Petri dishes (J.Prolab Ind. e comércio de produtos para laboratório LTDA., São José dos Pinhais, PR, Brazil) were gently swirled on a rotary shaker. Fluoride standards $(0.4,0.8,1.6,3.2$ and $6.4 \mu \mathrm{gF} / \mathrm{mL}$ ) were prepared by serial dilution of a stock-standard containing $100 \mu \mathrm{gF} / \mathrm{mL}$ of fluoride (Orion 940907 - Thermo Orion, Beverly, MA, USA) in triplicate and diffused in the same manner as the samples. Comparison with identical non-diffused fluoride standards showed that recovery after diffusion was $>99 \%$. The standard curve had a correlation coefficient 0.99 . All samples were analyzed in duplicate. The mean repeatability of the fluoride readings, based on the duplicate samples was $94.9 \%$.

\section{RESULTS}

Fluoride concentrations $(\mu \mathrm{gF} / \mathrm{g})$ in the different brands of fermented milk analyzed are shown in the Table 1. The fluoride concentration in the fermented milk of Parmalat ${ }^{\circledR}$ ranged from 0.022 $\mu \mathrm{gF} / \mathrm{g}$ to $0.031 \mu \mathrm{gF} / \mathrm{g}$, Nestlé $\circledR$ from $0.228 \mu \mathrm{gF} / \mathrm{g}$ to $0.272 \mu \mathrm{gF} / \mathrm{g}$, Paulista ${ }^{\circledR}$ from $0.182 \mu \mathrm{gF} / \mathrm{g}$ to 0.220 $\mu \mathrm{gF} / \mathrm{g}$, Batavo ${ }^{\circledR}$ from $0.028 \mu \mathrm{gF} / \mathrm{g}$ to $0.030 \mu \mathrm{gF} / \mathrm{g}$, Yakult $®$ from $0.115 \mu \mathrm{gF} / \mathrm{g}$ to $0.206 \mu \mathrm{gF} / \mathrm{g}$ and Vigor ${ }^{\circledR}$ from $0.808 \mu \mathrm{gF} / \mathrm{g}$ to $1.171 \mu \mathrm{gF} / \mathrm{g}$.

\section{DISCUSSION}

It is important to know all sources of fluoride ingestion that contribute to the total intake once the dental fluorosis is systemic caused by the excessive fluoride ingestion. Although the exact relationship between the consumption of industrialized beverages and dental fluorosis is not clear their ingestion contribute for the total fluoride intake specially the high fluoride content products, which never always highlight its content in the labels.

Many studies have demonstrated that it is necessary to know the fluoride concentration of infant foods, foodstuffs and beverages to estimate the total fluoride ingestion by children.,12,15 Although the total fluorine intake from the diet is difficult to be precisely determined, it is clear that there is substantial variation on the intake of different foods, foodstuffs and beverages, and in the fluoride content of these products. Since products are not required to have their fluoride content displayed, only a fluoride assay is possible to determine the dietary fluoride intake. ${ }^{3}$ All of the fermented milks analyzed in this study presented varied concentrations of fluoride, although none of the packages indicated that information.

The optimal level of systemic fluoride intake where it is believed to be active against caries and is not related to the development of dental fluorosis is not accurately known. Using rough estimative of the types and quantities of foods and drinks 
ingested and a technique less sensitive than the fluoride electrode to measure levels of fluoride, McClure ${ }^{16}$ estimated that the 'average daily diet' provided no more than 0.05 to $0.07 \mathrm{mg}$ fluoride/ $\mathrm{kg}$ body weight/day and that it did not exceed 0.10 $\mathrm{mg}$ fluoride/kg body weight/day for children aged 1 to 12 years. This figure has been extrapolated by some to be the 'optimal' level of intake, 9,17 while others ${ }^{2,18}$ have considered it to be the 'threshold' level of intake beyond which dental fluorosis may occur.

In this study, most of the fermented milks analyzed presented low concentrations of fluoride, less than $0.3 \mu \mathrm{gF} / \mathrm{g}$. However, the products of the brand Vigor ${ }^{\circledR}$ showed higher fluoride concentration ranged from $0.808 \mu \mathrm{gF} / \mathrm{g}$ to $1.171 \mu \mathrm{gF} / \mathrm{g}$. Considering that the 'optimal' level of fluoride intake ranges from 0.05 to $0.07 \mathrm{mgF} / \mathrm{Kg}$ body weight, those analyzed products can contribute significantly to the total ingestion of fluoride increasing the risk of the dental fluorosis development. In this sense, the consumption of $80 \mathrm{~g}$ of a fermented milk containing $1.171 \mu \mathrm{gF} / \mathrm{g}$ a day can contribute with about $0.008 \mathrm{mgF} / \mathrm{Kg}$ body weight for a child weighing $12 \mathrm{Kg}$ (approximately 2 years old). It is worth emphasizing that this dose $(0.008 \mathrm{mgF} / \mathrm{Kg})$ would be reached with the ingestion of only this beverage, without considering the other foods and beverages consumed during the day. Several reports have been showed high fluoride concentrations in foods typically consumed by children, such as powdered milks, ready-to-drink juices and chocolate milks, cereals and snacks. 3,5,6,19,20,21

The variation in fluoride concentrations among the lots is another issue that should be observed. In the present study, the lots of different brands presented variations ranged $16 \%$ to $44 \%$. In the brand Yakult $\circledast$, it was observed the largest difference among the analyzed lots. For beverages with low fluoride concentrations, these variations may have little impact on total fluoride intake. However, for products with high fluoride levels, such as the lot 2 of the brand Vigor $\circledR$, this variation can contribute significantly for the total intake of this ion. On the other hand, the bioavailability of milk is another point to be considered. Due to

Table 1. Fluoride concentration $(\mu \mathrm{g} / \mathrm{g})$ of the three lots in the different brands of fermented milk.

\begin{tabular}{|c|c|c|c|c|c|c|}
\hline Manufacturer & Brand & Production site & Lot & Mean & $\begin{array}{l}\text { Bottle total } \\
\text { fluoride }\end{array}$ & SD* \\
\hline \multirow{3}{*}{ Parmalat } & \multirow{3}{*}{ Fermented Milk skimmed sweeten - grape } & \multirow{3}{*}{ Carambeí-PR } & T3 & 0.031 & 2.48 & 0.0043 \\
\hline & & & M1 & 0.029 & 2.32 & 0.0038 \\
\hline & & & N1 & 0.022 & 1.76 & 0.0012 \\
\hline \multirow{3}{*}{ Nestlé } & \multirow{3}{*}{$\begin{array}{l}\text { Fermented Milk skimmed sweeten } \\
\text { Chamyto- vanilla }\end{array}$} & \multirow{3}{*}{ Araras-SP } & 7078132315 & 0.228 & 18.24 & 0.0007 \\
\hline & & & 7071132315 & 0.272 & 21.76 & 0.0114 \\
\hline & & & 7068132312 & 0.238 & 19.04 & 0.0057 \\
\hline \multirow{3}{*}{ Paulista } & \multirow{3}{*}{ Fermented Milk skimmed sweeten - vanilla } & \multirow{3}{*}{ Poços de Caldas-MG } & L 13:03 S3 & 0.185 & 14.80 & 0.0254 \\
\hline & & & L 15:48 S3 & 0.220 & 17.60 & 0.0046 \\
\hline & & & L04:52 S3 & 0.182 & 14.56 & 0.0060 \\
\hline \multirow{3}{*}{ Batavo } & \multirow{3}{*}{$\begin{array}{l}\text { Fermented Milk skimmed sweeten } \\
\text { Batavito - orange and citric fruits }\end{array}$} & \multirow{3}{*}{ Carambeí-PR } & L094 & 0.030 & 2.40 & 0.0029 \\
\hline & & & L103 & 0.030 & 2.40 & 0.0007 \\
\hline & & & L063 & 0.028 & 2.24 & 0.0022 \\
\hline \multirow{3}{*}{ Yakult } & \multirow{3}{*}{ Fermented Milk skimmed sweeten Yakult } & \multirow{3}{*}{ São Paulo-SP } & 57 & 0.115 & 9.20 & 0.0024 \\
\hline & & & 26 & 0.122 & 9.76 & 0.0040 \\
\hline & & & 90 & 0.206 & 16.48 & 0.0089 \\
\hline \multirow{3}{*}{ Vigor } & \multirow{3}{*}{$\begin{array}{l}\text { Fermented Milk skimmed sweeten } \\
\text { Vigor Club - vanilla }\end{array}$} & \multirow{3}{*}{ Lorena-SP } & 3 & 0.808 & 64.64 & 0.0300 \\
\hline & & & 2 & 1.171 & 93.68 & 0.0980 \\
\hline & & & 4 & 0.894 & 71.52 & 0.0294 \\
\hline
\end{tabular}

*: Standard Deviation 
the high calcium concentrations in milk, there is a possibility of diminution of fluoride absorption from gastro-intestinal tract. ${ }^{22,23}$ Thus, the calculations made for these products could be overestimated. Milk is also rich in fats, what are known to increase the lag time of the food or beverage in the stomach. ${ }^{23}$ Although milk interferes with the rate of fluoride absorption, it was demonstrated that 67 to $82 \%$ of total fluoride in milk is absorbed. ${ }^{24}$

Another crucial factor when the association between fluorosis and infant foods is the critical period of fluoride exposure to develop fluorosis. Enamel fluorosis can occur following acute or chronic exposure to fluoride during tooth formation assuming a significant relevance and emphasizing the importance of monitoring fluoride intake by little children.

\section{CONCLUSIONS}

In this study the presence of fluoride could be observed in all of the fermented milks analyzed which can contribute with the total fluoride daily intake.

\section{REFERENCES}

1. Aoba T, Fejerskov O. Dental fluorosis: chemistry and biology. Crit Rev Oral Biol Med 2002;13:155-170.

2. Burt BA. The changing patterns of systemic fluoride intake. J Dent Res 1992;71:1228-1237.

3. Buzalaf MAR, Granjeiro JM, Cardoso VE da S, Silva TL da, Olympio KPK. Fluorine content of several brands of chocolate bars and chocolate cookies found in Brazil. Pesqui Odontol Bras 2003;7:223-227.

4. Buzalaf MAR, Whitford GM, Cury JA. Fluoride exposures and dental fluorosis: a literature review. Rev Fac Odontol Bauru 2001;9:1-10.

5. Lodi CS, Ramires I, Pessan JP, Neves LT das, Buzalaf MAR. Fluoride concentrations in industrialized beverages consumed by children in the city of Bauru, Brazil. J Appl Oral Sci 2007;15:209-212.

6. Buzalaf MAR, Granjeiro JM, Damante CA, Ornelas F. Fluoride content of infant formulas prepared with deionized, bottled mineral and fluoridated drinking water. ASDC $J$ Dent Child 2001;68:37-41.

7. Johnson J Jr, Bawden JW. The fluoride content of infant formulas available in 1985. Pediatr Dent 1987;9:33-37.

8. Heilman JR, Kiritsy MC, Levy SM, Wefel JS. Fluoride concentrations of infant foods. J Am Dent Asssoc 1997;128:857863
9. Ophaug RH, Singer L, Harland BF. Dietary fluoride intake of 6-month and 2-year-old children in four dietary regions of the United States. Am J Clin Nutr 1985;42:701-707.

10. Ophaug RH, Singer L, Harland BF. Estimated fluoride intake for 6-month-old infants in four dietary regions of the United States. Am J Clin Nutr 1980;33:324-327.

11. Vlachou A, Drummond BK, Curzon MEJ. Fluoride concentrations of infant foods and drinks in the United Kingdom. Caries Res 1992;26:29-32.

12. Heilman JR, Kiritsy MC, Levy SM, Wefel JS. Assessing fluoride levels of carbonated soft drinks. J Am Dent Assoc 1999;130:1593-1599.

13. Kiritsy MC, Levy SM, Warren JJ, Guha-Chowdhury N, Heilman JR, Marshall T. Assessing fluoride concentrations of juices and juice-flavored drinks. J Am Dent Assoc 1996;127:895-902.

14. Taves DR. Separation of fluoride by rapid diffusion using hexamethyldisiloxane. Talanta 1968;15:969-974.

15. Levy SM, Kiritsy MC, Warren JJ. Sources of fluoride intake in children. J Public Health Dent 1995;55:39-52.

16. McClure FJ. Ingestion of fluoride and dental caries. Quantitative relations based on food and water requirements of children one to twelve years old. Am J Dis Child 1943;66:362-369.

17. Forrester DJ, Schulz EM. Proceedings of the intemational workshop on fluorides and dental caries reduction. Baltimore, MD: School of Dentistry, University of Maryland; 1974.

18. Fejerskov O, Stephen KW, Richards A, Speirs R. Combined effect of systemic and topical fluoride treatments on human deciduous teeth-case studies. Caries Res 1987;21:452459.

19. Almeida BS, Cardoso VES, Buzalaf MAR. Fluoride ingestion from toothpaste and diet in 1-3-year-old Brazilian children. Community Dent Oral Epidemiol 2007;35:53-63.

20. Buzalaf MAR, Damante CA, Trevizani LMM, Granjeiro JM. Risk of fluorosis associated to consumption of infant formulas prepared with bottled water. ASDC J Dent Child 2004;71:110-113.

21. Buzalaf MAR, Granjeiro JM, Duarte JL, Taga MLL. Fluoride content of infant foods in Brazil and risk of dental fluorosis. ASDC J Dent Child 2002;69:196-200.

22. Spak CJ, Hardell LI, De Chateau P. Fluoride in human milk. Acta Paediatr Scand 1983;72:699-701.

23. Trautner K, Siebert G. An experimental study of bio-availability of fluoride from dietary sources in man. Arch Oral Biol 1986;31:223-228.

24. Spak CJ, Ekstrand J, Zylberstein D. Bioavailability of fluoride added to baby formula and milk. Caries Res 1982;16:249-256. 